sunspots of this order of size are very likely to be associated with geomagnetic storms beginning within the time-limits of two days before and four days after central meridian passage of the spot group. A severe geomagnetic storm did, in fact, occur, commencing abruptly on January 24 at $18 \mathrm{~h} .28 \mathrm{~m}$. U.T. The disturbance continued with even increased vigour to the night of January 25-26. Displays of the aurora were widely seen on both nights in Great Britain. Provisional overall ranges recorded at Abinger of the earth's magnetic elements (kindly communicated by the Astronomer Royal) are as follow: $D, 1^{\circ} 29^{\prime} ; H, 660 \gamma ; V, 490 \gamma$. Long-distance radio-communication was seriously affected during the period of the geomagnetic storm.

Although a close connexion between the magnetic storm and the solar region containing this giant spot group can scarcely be doubted, there is little evidence at present for the occurrence of a brilliant solar flare some 24 hours before storm onset. Such a flare may have occurred, however, during the Greenwich night hours, and observations are being sought from observatories recording during $18 \mathrm{~h},-0 \mathrm{~h} .-6 \mathrm{~h}$. U.T. either (a) direct solar observations; (b) radio anomalies that occur in the earth's day hemisphere when flares occur; or (c) a characteristic 'crochet' impulse on magnetograms that likewise betrays the occurrence of the more intense flares. Apart from this, there is increasing evidence that the stream of solar particles involved in the occurrence of a great magnetic storm is ejected at the time of an intense flare within the centrgy region of the sun's disk.

\section{Geological Survey in the British Commonwealth}

IN an article in th Petroleum Times of January 1949, a "Petpley Geologist" puts forward proposals for $\mathrm{g}$ (tish and Commonwealth plan for a modern ge lagical survey. He lays emphasis on the fundam ntal importance of geological survey, and on the urg pht need for an appraisal of the mineral restres of the Commonwealth. He recognizes that the development of the surveys depends on the expansion and training of staff and on the provision of specialist services in such fields as palæontology, geophysics and air survey. The lay-out of the organisation which he advocates accepts the essential independence of the surveys of the several Dominions, but involves a closer relationship between the Geological Survey of Great Britain and the Colonial geological surveys; he proposes that these should be placed under a Minister (or his nominee) with an advisory board, and that specialist services should be joint. The comparison with the organisation of some oil companies is not helpful, however; both in Britain and in the Colonies, geological surveys have a much wider range of interest than an oil company, and procedures suitable for the rapid exploration of oil resources are not necessarily adaptable for a survey which, to be economical, must deal concurrently with many topics. Moreover, while it is true that greater freedom of interchange between Britain and the rest of the Commonwealth is valuable, the differences in the nature of the problems met with, and the importance of individuals with great local knowledge, limit the possibilities of useful interchange. We believe that the Geological Survey of Great Britain is itself as fully engaged on economic problems as "Petroleum Geologist" could desire, while the new organisation of the Colonial surveys promises important and rapid progress as men can be recruited.

\section{Autumn Bird Migration in Britain}

SeVEral very inteyesting items occurred during the autumn of 19. shank (Totat melanoleucus), the sixth British record, appeared a Ecton Sewage Farm, Northamptonshire, wheref grey phalarope, the first county record since 192 , Ind an osprey appeared in September. On Seftember 13 an American pectoral sandpiper (Calidris melanotis) appeared at Salthouse Marsh in Norfolk, another was reported from Sinderland, in Cheshire, on September 10, and a third at Thorney Island, Sussex, on October 3. On September 9 an immature cormorant (Phalocrocorax carbo) with four legs was obtained at Seaforth, Lancashire; later it died in Liverpool, but X-ray and other photographs were taken for the Merseyside Naturalists'Association. A grey phalarope also appeared at Worsley Sewage Farm, Lancashire, on September 5. On November 11 a little bunting (Emberiza pusilla) was added to the bird records of Cumberland by R. Stokoe, a careful observer, at a roadside pool at Siddick, near Workington. Whooper swans were on the same water, and earlier that month on Derwentwater. A gadwall was shot at Frodsham, Cheshire, early in December. Ringed bird returns have included this season a turnstone in Cheshire, marked by Stavanger ornitho. logical station in Norway; and a Manx shearwater found at Leigh, Lancashire (an inland location), on September 5, was marked at the Skokholm colony, South Wales, as recently as August 28.

\section{The Animal Health Trust}<smiles></smiles>

REviEwING the ten-monthly period ending June 1948, the secon Neport of the Animal Health Trust describes the mpletion of the requisition of land and builyins for the Trust's Canine Research Station a Newmarket and the Farm Livestock Repald Station at St. Ives. At the former, research his been restricted to studies of a clinical nature incltding para-distemper, night blindness and Scotch cramp, while at the Poultry Research Station, established on the fifty-acre parkland adjoining Houghton Grange, St. Ives, diseases of the respiratory track have been the priority subjects of investigation. Progress has also been made in the investigations being carried out at the Equine Research Station at Balaton Lodge and Lanwades Park, Newmarket, into infertility, parasitology and diseases of foalhood. During the ten months, the Trust has granted a number of research fellowships to individual workers who wished to continue investigations of an independent nature, and helped some veterinary surgeons to go abroad to widen their experience. Six county committees of the Trust have been formed and eleven others are in the process of being established.

\section{Zoological Society of Bengal : New Journal 5\%}

Zoologists wiltoe interested in the appearance of vol. 1, No. 1. Ne Proceedings of the Zoological Society of Bengah thich, it is announced, will be published twice yearly and will contain the results of original reseaf in the various branches of zoology. The fint number (obtainable from the Society at 35 Bal gunge Circular Road, Calcutta; price 5 Rs. or 10s.) comprises 78 pages and 4 plates; and it contains eight papers covering a wide field, contributed mainly by the Department of Zoology of the University of Calcutta. S. P. R. Chaudhuri and I. Bose give an account of meiosis in diploid and tetraploid 